\title{
EDITORIAL
}

\section{Genomics elucidates both common and rare disease aetiology}

(c) The Author(s), under exclusive licence to European Society of Human Genetics 2021

European Journal of Human Genetics (2021) 29:1725-1726; https://doi.org/10.1038/s41431-021-01001-w

Welcome to the final issue of European Journal of Human Genetics for 2021. We close the year with a range of interesting and informative papers. Birth defects (congenital anomalies) affect many thousands of neonates every year; yet the aetiology of many of them remains unresolved. Schreiner et al review what is known about the genomic basis of congenital diaphragmatic hernia $(\mathrm{CDH})$ [1]. Around $10 \%$ of cases of $\mathrm{CDH}$ are associated with a copy number variant. Implicated pathways include NRF2 and vitamin A homeostasis. In contrast to common malformations, the genetic basis of rare disease continues to be elucidated with more and more causal genes identified annually [2-4]. Guo and colleagues identify variants in SLIRP as a novel cause of mitochondrial disease [5]. In this issue, variants in IMPDH2 are associated with dystonia in a large family [6]; IMPDH2 acts in the dopamine synthesis pathway previously implicated in the aetiology of dystonia. Of course, even with modern technology there remain patients for whom a molecular genetic diagnosis remains elusive. Pham et al demonstrate that variants in DLK4 are not responsible for Silver-RussellSyndrome [7].

Kawasaki disease is a paediatric vasculitis with a risk of coronary artery involvement. In this month's EJHG Hoggart et al identify a potential genetic risk factor for coronary artery involvement in Kawasaki disease [8]. For many genetic diseases, little is known about population epidemiology. In a study of malignant hyperthermia gene variants in Iceland, it was estimated that 1/ 1450 Icelanders carry an actionable variant in a malignant hyperthermia gene [9]. Keratoconus (defined as noninflammatory corneal ectasia) is of uncertain aetiology. Fransen et al identify a shared genetic link between keratoconus and the connective tissue disease Ehlers-Danlos syndrome [10]. Male factor infertility is frequently of unknown aetiology. Arafat and colleagues identify variants in GCNA in association with low sperm count and impared sperm motility [11].

Not all (rare) disease is monogenic (that is explained by variants in a single gene). In an Indian study, 14 families with clinical phenotypes associated with causal variants in more than one mendelian disease gene are reported [12]. The clinical consequences were described as blended phenotypes, a mild phenotype from gene A being obscured by a severe phenotype from gene $B$ or 2 distinct phenotypes in the same patient. Undoubtedly such multilocus variation has the potential to contribute to phenotype variability in genetic diseases. Sharing information on pathogenic gene variants is crucial to help clinical reporting. The updated LOVD3 platform provides one mechanism for doing so [13].

All genomics research must be ethically approved and adhere to conditions set by the relevant committees. But do research ethics committees have sufficient understanding to review and grant permission for ethically robust genomics research? A study of Australian research ethics committees highlights a potential need for extra training for committee members [14].

\author{
Alisdair McNeill ${ }^{1,2}$ 厌 \\ ${ }^{1}$ Department of Neuroscience, The University of Sheffield, Sheffield, \\ UK. ${ }^{2}$ Sheffield Clinical Genetics Department, Sheffield Children's \\ Hospital NHS Foundation Trust, Sheffield, UK. ${ }^{\bowtie}$ email: $a$. \\ moneill@sheffield.ac.uk
}

\section{REFERENCES}

1. Schreiner Y, Schaible T, Rafat N. Genetics of diaphragmatic hernia. Eur J Hum Genet. 2021. https://doi.org/10.1038/s41431-021-00972-0

2. Traynor BJ, Gottesman RF. The value of studying rare genetic variants and other emerging themes in neurogenetics. Brain. 2021;144:2555-6.

3. Matalonga L, Hernández-Ferrer $C$, Piscia D, Solve-RD SNV-indel working group, Schüle $R$, Synofzik $M$, et al. Solving patients with rare diseases through programmatic reanalysis of genome-phenome data. Eur J Hum Genet. 2021;29:1337-47.

4. de Boer E, Ockeloen CW, Matalonga L, Horvath R, Solve-RD SNV-indel working group, Rodenburg RJ, et al. A MT-TL1 variant identified by whole exome sequencing in an individual with intellectual disability, epilepsy, and spastic tetraparesis. Eur J Hum Genet. 2021;29:1359-68.

5. Guo L, Engelen BPH, Hemel IMGM, de Coo IFM, Vreeburg M, Sallevelt SCEH, et al. Pathogenic SLIRP variants as a novel cause of autosomal recessive mitochondrial encephalomyopathy with complex I and IV deficiency. Eur J Hum Genet. 2021. https://doi.org/10.1038/s41431-021-00947-1

6. Kuukasjärvi A, Landoni JC, Kaukonen J, Juhakoski M, Auranen M, Torkkeli T, et al. IMPDH2: a new gene associated with dominant juvenile-onset dystonia-tremor disorder. Eur J Hum Genet. 2021. https://doi.org/10.1038/s41431-021-00939-1

7. Pham A, Sobrier ML, Giabicani E, Le Jules Fernandes M, Mitanchez D, Brioude F, et al. Screening of patients born small for gestational age with the Silver-Russell syndrome phenotype for DLK1 variants. Eur J Hum Genet. 2021. https://doi.org/ 10.1038/s41431-021-00927-5

8. Hoggart C, Shimizu C, Galassini R, Wright VJ, Shailes H, Bellos E, et al. Identification of novel locus associated with coronary artery aneurysms and validation of loci for susceptibility to Kawasaki disease. Eur J Hum Genet. 2021. https://doi.org/ 10.1038/s41431-021-00838-5

9. Fridriksdottir R, Jonsson AJ, Jensson BO, Sverrisson KO, Arnadottir GA, Skarphedinsdottir SJ, et al. Sequence variants in malignant hyperthermia genes in Iceland: classification and actionable findings in a population database. Eur J Hum Genet. 2021. https://doi.org/10.1038/s41431-021-00954-2

10. Fransen $E$, Valgaeren $H$, Janssens $K$, Sommen M, De Ridder R, Vandeweyer $G$, et al. Resequencing of candidate genes for Keratoconus reveals a role for Ehlers-Danlos Syndrome genes. Eur J Hum Genet. 2021. https://doi.org/10.1038/ s41431-021-00849-2

11. Arafat $M$, Kleiman $S E$, AbuMadighem A, Zeadna A, Levitas E, Vardi IH, et al. Pathogenic variations in Germ Cell Nuclear Acidic Peptidase (GCNA) are associated with human male infertility. Eur J Hum Genet. 2021. https://doi.org/10.1038/s41431-021-00946-2

12. Narayanan DL, Udyawar D, Kaur $P$, Sharma $S$, Suresh $N$, Nampoothiri $S$, et al. Multilocus disease-causing genomic variations for Mendelian disorders: role of systematic phenotyping and implications on genetic counselling. Eur J Hum Genet. 2021. https://doi.org/10.1038/s41431-021-00933-7

13. Fokkema IFAC, Kroon M, López Hernández JA, Asscheman D, Lugtenburg I, Hoogenboom J, et al. The LOVD3 platform: efficient genome-wide sharing of genetic variants. Eur J Hum Genet. 2021. https://doi.org/10.1038/s41431-021-00959-x

14. Pysar R, Wallingford CK, Boyle J, Campbell SB, Eckstein L, McWhirter R, et al. Australian human research ethics committee members' confidence in reviewing genomic research applications. Eur J Hum Genet. 2021. https://doi.org/10.1038/ s41431-021-00951-5 
1726

AUTHOR CONTRIBUTIONS

Alisdair meneill conceptualised and wrote this article.

COMPETING INTERESTS

The authors declare no competing interests.

\section{ADDITIONAL INFORMATION}

Correspondence and requests for materials should be addressed to Alisdair McNeill.

Reprints and permission information is available at http://www.nature.com/ reprints

Publisher's note Springer Nature remains neutral with regard to jurisdictional claims in published maps and institutional affiliations. 